\title{
Jurnalisme Bencana di Indonesia, Setelah Sepuluh Tahun
}

\author{
Muzayin Nazaruddin \\ Program Studi Ilmu Komunikasi, Universitas Islam Indonesia
}

\begin{abstract}
Abstrak
Indonesia adalah salah satu negeri rentan bencana. Ketika sebuah bencana terjadi, masyarakat selalu ingin tahu tentang berbagai hal mengenai bencana tersebut, misalnya tentang penyebab, korban, kerugian, dampaknya secara luas, penanggulangan, dan lainnya. Dalam situasi ketidakpastian yang ditimbulkan bencana, kebutuhan masyarakat terhadap berita-berita bencana akan meningkat tajam. Kebutuhan informasi seputar bencana yang meningkat tajam ini menggerakkan liputan bencana yang intensif dari media massa. Mediamedia di Indonesia masih menunjukkan euforia saat memberitakan bencana. Sebagian besar media hanya mengeksploitasi bencana sebagai 'kisah satir yang menghibur', dengan berbagai praktik dramatisasi, demi kepentingan akumulasi modal semata.
\end{abstract}

Kata kunci: bencana, berita,jurnalisme, peran media

\section{Latar Belakang}

Indonesia adalah salah satu negeri rentan bencana, baik dari aspek geologis, klimatologis, maupun sosial demografis (Sudibyakto et.al. 2012: 7). Dari aspek geologis, kepulauan Indonesia termasuk dalam wilayah Pacific Ring of Fire (Deretan Gunung Berapi Pasifik), yang bentuknya melengkung dari Pulau Sumatera, Jawa, Nusa Tenggara, hingga Sulawesi Utara. Selain itu, Indonesia juga terletak di pertemuan dua lempeng tektonik dunia dan dipengaruhi oleh tiga gerakan, yaitu Gerakan Sistem Sunda di bagian barat, Gerakan Sistem Pinggiran. Asia Timur dan Gerakan Sirkum Australia (www.walhi.or.id/kampanye/bencana).

Faktor geologis tersebut menyebabkan Indonesia rentan terhadap letusan gunung berapi, gempa bumi, dan tsunami. Dari aspek iklim, sebagai negara tropis, Indonesia memiliki kerentanan tinggi karena ancaman banjir, tanah longsor, dan wabah penyakit.

\footnotetext{
j Aspek sosial demografis juga sangat berperan meningkatkan kerentanan terhadap bencana. Pertama, keragaman budaya, etnis, serta agama, di
}

satu sisi menjadi kekayaan, namun di sisi lain menjadi potensi bencana jika tidak dikelola dengan baik, karena bisa mengarah pada bencana sosial. Kedua, kesenjangan perekonomian yang sangat tinggi serta tidak meratanya akses kepada berbagai sumber daya hidup memaksa banyak kelompok masyarakat hidup di daerah yang sangat rentan bencana, seperti wilayah perbukitan, bantaran sungai, pembuangan limbah, atau wilayah kumuh perkotaan lainnya. Mereka yang tidak memiliki akses terhadap pemukiman yang layak tersebut biasanya juga tidak memiliki akses terhadap kebutuhan dasar lainnya, sehingga kemampuannya bertahan dalam kondisi bencana menjadi sangat lemah (Sudibyakto et.al. 2012: 1618).

Beberapa kondisi tersebut menyebabkan masyarakat Indonesia secara umum berada dalam kondisi rentan bencana. Secara mendasar, bencana adalah sebuah peristiwa, baik peristiwa alam, sosial, politik, atau lainnya, yang mengakitkan kerugian bagi manusia, baik material maupun immaterial. Bencana alam diakibatkan oleh ketidakberdayaan manusia berhadapan dengan fenomena 
alam, akibat kurang baiknya manajemen keadaan darurat, sehingga menyebabkan kerugian keuangan, struktural, bahkan kematian. Dalam pemahaman ini, bencana muncul bila ancaman bahaya bertemu dengan ketidakberdayaan manusia (Bankoff et.al. 2004).

Dalam dunia yang semakin terhubung satu sama lain dan mengglobal, sebuah bencana tidak akan terjadi dalam sebuah ruang yang terisolasi. Sebaliknya, sebuah bencana akan menjadi peristiwa lokal, nasional, atau bahkan internasional, tergantung luasnya daerah yang terpapar, besarnya efek, kerugian dan korban. Karena itu, bencana akan menjadi peristiwa yang membekas secara psikologis dan sosial, tidak hanya bagi orang-orang yang menjadi korban, namun juga bagi masyarakat secara luas. Ketika sebuah bencana terjadi, masyarakat selalu ingin tahu tentang berbagai hal mengenai bencana tersebut, misalnya tentang penyebab, korban, kerugian, dampaknya secara luas, penanggulangan, dan lainnya. Dalam situasi ketidakpastian yang ditimbulkan bencana, kebutuhan masyarakat terhadap berita-berita bencana . akan meningkat tajam. Kebutuhan informasi seputar bencana yang meningkat tajam ini menggerakkan liputan bencana yang intensif dari media massa. Dalam posisi tersebut, media memegang. kuasa yang besar karena masyarakat menggantungkan sumber informasi tentang bencana dari media. Selain itu, antusiasme media meliput bencana juga berangkat dari karakter bencana itu sendiri sebagai even besar yang mengandung daya tarik luar biasa, tanpa perlu direkayasa. Semakin besar spektrum dan semakin luas wilayah yang terpapar bencana, liputan media pun akan semakin intensif dan panjäng.

Sayang, seperti ditunjukkan beberapa kajian (Yusuf 2006; Masduki 2007; Lukmantoro 2007; Nazaruddin 2007; Nazaruddin 2012), potensi kuasa yang besar tersebut kurang dimanfaatkan oleh berbagai media di Indonesia. Mediamedia di Indonesia masih menunjukkan euforia saat memberitakan bencana. Sebagian besar media hanya mengeksploitasi bencana sebagai kisah satir yang menghibur', dengan berbagai praktik dramatisasi, demi kepentingan akumulasi modal semata. Dalam kacamata bisnis media, bencana adalah 'blessing in disquise', menjadi sumber informasi yang tidak pernah kering dengan kandungan nilai berita yang tinggi.

\section{Kajian Peran Media dalam Bencana}

Salah satu tema mendasar dalam kategori ini adalah pengaruh berita-berita bencana terhadap audiens. Gama (2009) yang meneliti berita-berita bencana banjir tahun 2007 di Solo membuktikan bahwa pemberitaan bencana, khususnya nilainilai berita timeliness, consequence, human interest, dan magnitude, mempengaruhi rangsangan emosional audiens.

Joe Hight dan Cait McMahon, Direktur Dart Centre for Journalism and Trauma, menunjukkan sebuah kecenderungan global peliputan bencana bahwa media seringkali menjadi kutu loncat, melompat dari isu bencana ke isu lainnya. Hasilnya, pemberitaan bencana tidak pernah tuntas karena terdesak oleh berbagai isu lain yang tidak kalah seksi, mudah diburu, dan tidak memerlukan mekanisme serius untuk menampilkannya di media. Menurut mereka (Hight \& McMahon 2006), "Setelah dua hingga empat minggu, tergantung dari dimensi apa yang terjadi, iring-iringan mulai bergerak. Media menemukan headlineheadline baru. Orang dibiarkan menjalani kehidupan mereka sendiri."

Kecenderungan kutu loncat tersebut juga biasa dilakukan mediamedia di Indonesia (Hermawan 2007). Dalam hal ini, Masduki mangajukan kritik tentang tidak adanya kesinambungan dalam pemberitaan bencana, yang ada adalah berita yang terpenggal-penggal, tidak tuntas, tidak mendalam dan absurd. Berita-berita bencana tersebut tidak memiliki visi dan orientasi menuju rehabilitasi (Masduki 2007). 
Dalam hal tema pemberitaan, beberapa kajian menunjukkan bahwa media berkutat pada penggambaran bencana secara dramatis dan traumatis, berisi cerita isak tangis, ekspresi sedih, ataupun nestapa korban, dengan dalih menumbuhkan solidaritas (Masduki 2007; Yusuf 2006). Gejala dramatisasi tersebut juga bukan monopoli mediamedia di Indonesia, namun merupakan gejala global dalam dunia jurnalistik. Hight dan McMahon (2006) mengatakan bahwa dalam fase-fase awal paskabencana seringkali ada kabar angin yang sangat dramatis, misalnya angka kematian yang dibesar-besarkan, ketakutan dan kekacauan sosial.

\section{Menurut Greg Philo (2002: 173-} 186), kecenderungan televisi memberitakan perang, konflik dan bencana secara dramatis dan parsial berakibat pada minimnya pemahaman àudiens tentang kejadian-kejadian yang diberitakan. Hal ini adalah hasil ideologi rating dalam industri televisi yang mengarahkan pemberitaan televisi pada gambaran dramatis, kekerasan dan tragedi, dengan penjelasan yang sangat minim mengenai peristiwa itu sendiri. Karena ketiadaan penjelasan ini, audiens kemudian mengisi gap yang ada dengan kepercayaan-kepercayaan neokolonial mengenai dunia ketiga. Dalam kesimpulan Philo (2002: 185), "This is in part the result of television coverage that tends to focus on dramatic, violent and tragic images while giving very little context or explanation to the events that are being portrayed."
Selain itu, pemberitaan televisi tentang peristiwa traumatis mempunyai efek permanen dalam jangka panjang. Sorin Adam Matei dan Sandra BallRokeach menyimpulkan bahwa televisi mempunyai peranan sentral dalam menanamkan stigma buruk kepada khalayak tentang suatu tempat atau peristiwa secara relatif permanen (Matei dan Ball-Rokeach, 2005: 301-323).

Tema Iain yang sering dibahas adalah hubungan antara liputan media dengan bantuan bencana. Olsen, Carstensen dan Hoyen (2003: 109-126) menyebut media sebagai salah satu faktor yang turut memainkan peran dalam mempengaruhi donor untuk mengalokasikan sejumlah besar bantuan pada kondisi darurat paskabencana. Namun, peran media tidak lebih penting dibandingkan kepentingan donor itu sendiri, yang notabene adalah negaranegara Barat. Media memainkan peran krusial dalam mempengaruhi para pengambil keputusan ketika para pengambil keputusan tersebut tidak memiliki isu keamanan atau isu vital lainnya di wilayah bencana. Ketika krisis kemanusiaan terjadi di lokasi dimana negara-negara Barat tidak memiliki kepentingan strategis, krisis tersebut berpeluang besar menjadi forgotten crises'. Dalam kasus seperti ini, liputan intensif media internasional dan kerja keras lembaga-lembaga kemanusiaan setempat sangat menentukan jumlah bantuan yang akan diterima para korban bencana. Olsen, Carstensen dan Hoyen membandingkan liputan media di dua buah bencana, yaitu angin topan di India (1999) dan banjir di Mozambique (2000). 
Tabel 1.1.

Perbandingan liputan media dan jumlah bantuan bencana

\begin{tabular}{|l|l|l|}
\hline & \multicolumn{1}{|c|}{$\begin{array}{c}\text { Angin topan India } \\
\text { (1999) }\end{array}$} & \multicolumn{1}{|c|}{$\begin{array}{c}\text { Banjir Mozambique } \\
\text { (2000) }\end{array}$} \\
\hline $\begin{array}{l}\text { Berita di televisi nasional } \\
\text { Denmark (DR-TV \& TV) }\end{array}$ & 16 & 87 \\
\hline $\begin{array}{l}\text { Tulisan di 23 koran di } \\
\text { Amerika dan Eropa }\end{array}$ & 91 & 382 \\
\hline $\begin{array}{l}\text { Jumlah korban } \\
\text { meninggal }\end{array}$ & 10.000 & 800 \\
\hline Jumlah kerugian & 12,6 juta US dolar & 1,5 juta US dolar \\
\hline Jumlah bantuan diterima & 23.097 .000 US dolar & 165.846 .000 US dolar \\
\hline
\end{tabular}

Sumber: Olsen, Carstensen dan Hoyen (2003)

Tabel di atas dengan jelas menunjukkan bahwa banjir di Mozambique, dengan jumlah korban dan kerugian jauh lebih kecil dibandingkan angin topan di India, ternyata mendapat liputan media yang jauh lebih banyak dan jumlah bantuan yang juga jauh lebih besar. Mengapa? Olsen, Carstensen dan Hoyen dengan jelas menyebut faktor aksesibilitas dan bingkai media sebagai faktor penentu. Mereka menjelaskan, setelah beberapa hari paskabencana, akses pada wilayah bencana dan transportasi sangat mudah di Mozambique. Bahkan, para reporter dengan didampingi otoritas setempat menuju daerah-daerah yang belum terjamah bantuan dan mendapatkan gambar-gambar yang sangat dramatis. Sebaliknya, di India akses kepada wilayah bencana jauh lebih kompleks, pemerintah mendeklarasikan keadaan darurat dan menentukan 'no-go zone for most of the affected areas'. Liputan media terbatas di wilayah-wilayah yang aman. Faktor kedua adalah bingkai media. Olsen, Carstensen dan Hoyen (2003: 115) menyimpulkan:

"Put simply, the world had never before on TV seen a woman give birth to a child in a treetop while the viewers simultaneously could hear the dramatic sound of rotor blades on the South African helicopter hovering over the woman. And never before had TV shown such a spectacular rescue operation involving a considerable number of people being rescued from treetops by helicopters. Thus, framing was no doubt important in the Mozambican case."

Masduki (2007) menyoroti fenomena unik yang terjadi di Indonesia, yaitu fungsi ganda media dalam bencana, fungsi jurnalistik sebagai penyebar informasi dan fungsi sosial karitatif sebagai lembaga pengumpul dan penyalur bantuan bencana. Ternyata, media lebih antusias berperan sebagai lembaga pengumpul dan penyalur bantuan bencana daripada berkonsentrasi pada peran jurnalistiknya dalam bencana. Seolah-olah media yang paling berjasa adalah media yang berhasil mengumpulkan nominal sumbangan tertinggi. Peran sosial karitatif ini kontradiktif dan menghambat fungsi jurnalistik media sebagai watchdog atau lembaga kontrol dalam penyaluran berbagai bantuan bencana. Logikanya, menurut Masduki, bagaimana mungkin media melakukan kontrol atas penyaluran bantuan bencana jika media itu sendiri terlibat sebagai lembaga penyalur bencana. 
Kajian Representasi Bencana di Media

Peneliti menemukan tiga buah penelitian terdahulu yang secara khusus membahas representasi bencana erupsi Merapi di media, yaitu penelitian yang dilakukan Ahimsa-Putra (2000), Hudayana (2012) dan Fauzanafi (2012). Ahimsa-Putra (2000) menemukan tiga kelompok tafsir atas erupsi Merapi di media massa, yang bersaing satu sama Iain, yaitu tafsir peringatan yang biasa dikemukakan tokoh spiritual, tafsir cobaan yang biasa diajukan pejabat pemerintahan, dan tafsir takdir yang biasa dipegang para korban bencana. Jelas bahwa ketiga jenis tafsir tersebut berangkat dari sebuah keyakinan religius tertentu, yang sama sekali berbeda dengan keyakinan tradisional orang-orang lokal Merapi yang mempercayai erupsi sebagai sebuah peristiwa mistik yang disebabkan makhluk halus penunggu gunung Merapi (Triyoga 2010: 56-70, Dove 2008: 332, Donovan 2010: 122). Dalam hal ini, orangorang Merapi biasa menyebut erupsi sebagai 'Merapi duwe gawe'.

Hudayana (2012) meneliti pemberitaan harian Kedaulatan Rakyat (KR) atas erupsi Merapi tahun 2004. Hudayana menyimpulkan bahwa wacana erupsi Merapi di KR merepresentasikan alam pikiran mistis orang Jawa tentang bencana alam. KR bahkan sepertinya menjadi referensi bagi orang Jawa untuk mencari penjelasan mistis atas peristiwa bencana, dampaknya, serta tafsir sosial politik yang mengikutinya. Erupsi Merapi ditampilkan $\mathrm{KR}$ sebagai sesuatu yang menakutkan dan berbahaya, kadang tidak bisa diprediksi bahkan oleh teknologi sekalipun, dan menawarkan jalan keluar dengan selalu waspada. Selain itu, di bawah kontrol Orba, berita seputar erupsi selalu sarat dengan agenda pemerintah yang mencitrakan dirinya sebagai juru selamat dan pelindung masyarakat.

Fauzanafi (2012) meneliti 1456 foto tentang erupsi Merapi di empat koran, yaitu Kompas Nasional, Kompas Yogyakarta, Kedaulatan Rakyat, dan Pikiran Rakyat, dalam kurun waktu satu bulan paska letusan Merapi tahun 2010.
Dari total foto tersebut, tercatat 975 foto yang bisa dimasukkan ke dalam kategori tertentu, sisanya ( 481 foto) tidak begitu berkaitan dengan bencana erupsi Merapi. Terdapat beberapa tema foto yang sangat sering muncul. Pertama, tema pemberian bantuan, biasanya foto menggambarkan orang yang tengah memberikan sesuatu kepada perwakilan koran atau korban. Kedua, foto bertema pengungsian, yang seringkali menampilkan kelompok rentan yang berdesak-desakan di pengungsian. Ketiga, foto wajah tokoh, artis, atau ahli, yang menimbulkan pertanyaan, apakah mereka sekadar menebar pesona.

Secara khusus, penelitian Fauzanafi memiliki objek material yang sama dengan penelitian ini, yaitu foto-foto di media tentang bencana erupsi Merapi 2010. Namun, penelitian ini berbeda dengan penelitian terdahulu tersebut. dengan objek kajian yang sangat luas, Fauzanafi berupaya melakukan pemetaan tematik terhadap foto-foto erupsi Merapi 2010. Namun, penelitian ini tidak membahas bagaimana konstruksi pengetahuan yang dibangun foto-foto tersebut. Sementara, dengan objek penelitian yang terbatas hanya foto-foto headline, penelitian ini akan membahas bagaimana wacana yang dibangun fotofoto tentang erupsi Merapi tahun 2010.

Dua penelitian terdahulu lainnya, yang dilakukan Ahimsa-Putra dan Hudayana, mempunyai objek kajian yang berbeda dalam aspek waktu, karena membahas wacana erupsi Merapi tahun 1994. Oleh karena itu, temuan-temuan di dua penelitian terdahulu tersebut sangat mungkin bisa dibahas dan dibandingkan dengan hasil-hasil penelitian ini untuk melihat perubahan atau pergeseran wacana yang terjadi. Walaupun, perlu ditegaskan di sini, penelitian ini tidak dimaksudkan sebagai studi perbandingan antara wacana erupsi tahun 1994 yang telah dibahas dua penelitian terdahulu tersebut dengan wacana erupsi tahun 2010.

Selain tiga penelitian tersebut, peneliti juga menemukan beberapa penelitian lainnya tentang representasi bencana di media. Semua penelitian 
tersebut secara tidak langsung menunjukkan bahwa bencana adalah sebuah praktik diskursif. Definisi sebuah peristiwa sebagai bencana, analisis penyebab, ataupun perbincangan tentang langkah-langkah tanggap darurat dan rehabilitasi paskabencana, adalah praktik diskursif yang dibentuk oleh relasi-relasi kuasa yang kompleks dalam sebuah bencana yang terjadi.

Wahyuni (2008: 307-329) membahas kecenderungan framing media dalam pemberitaan bencana tahun 20062007, meliputi gempa bumi Yogyakarta, Mei 2006; gempa bumi Padang, Maret 2007; tenggelamnya Kapal Senopati, Desember 2006; kecelakaan Adam Air, Januari 2007; serta bencana lumpur Lapindo, Mei 2006 - Maret 2007. Lepas dari ketidakjelasan media dan teks yang diteliti, yang sangat mungkin menimbulkan pertanyaan tentang overgeneralisation atas kesimpulan yang ditarik, kajian ini tetap berguna untuk melihat kecenderungan umum framing media dalam pemberitaan bencana. Kajian ini menemukan beberapa kecenderungan pemberitaan bencana. Pertama, pada bencana yang murni disebabkan alam, seperti gempa bumi Yogya dan Padang, pemberitaan media lebih terfokus pada penanggulangan paskabencana. Tentang kecelakaan transportasi, media menonjolkan bingkai konflik, etika-hukum, kemajuan, dan personalisasi. Dalam kasus lumpur Lapindo, bingkai media berkait dengan analisis sebab melubernya lumpur, skenario penyelesaian, serta penderitaan korban. Secara umum, media berkutat dalam wacana tuntutan dan gugatan atas ketidakberdayaan pemerintah dalam penanggulangan bencana.

Lukmantoro (2007: 44-60) mencermati pemberian julukan pada beragam bencana, misal "Tsunami Aceh", "Gempa Jogja", atau "Banjir Jakarta". Praktik tersebut merupakan komodifikasi sekaligus simplifikasi, mengaitkan bencana dengan nama-nama yang sangat dikenal khalayak. Simplifikasi terjadi karena sebenarnya bencana adalah masalah yang sangat kompleks.
Purwoko (2007: 130-148) menganalisis berita tentang banjir Jakarta pada Februari 2007 di lima koran, yaitu: Kompas, Seputar Indonesia, Suara Merdeka, Wawasan, dan Jawa Pos. Purwoko menyimpulkan, berita di mediamedia tersebut menunjukkan bahwa banjir di Jakarta bukan disebabkan faktor alam, namun disebabkan faktor tata kota dan sosial politik, hingga banjir tersebut tak pernah selesai.

Laksono (2007) menganalisis berita-berita, khususnya foto-foto, tentang gempa Yogya tahun 2007 di dua koran lokal, yaitu Kedaulatan Rakyat dan Bernas Jogja. Pada minggu pertama, dalam kondisi darurat, apa saja yang berkaitan dengan gempa akan diberitakan, biasanya dalam bentuk straight news. Karenanya, tema liputan sangat beragam. Memasuki minggu kedua, mulai muncul pemberitaan sektoral, misalnya sektor kesehatan dengan isu merebaknya penyakit. Pada fase ini, media mulai berada satu posisi dengan negara, penggambarannya menjadi konvensional terlembaga, berisi penyederhanaan dengan berbagai angka statistik. Tidak ditemukan lagi visualisasi gempa yang dahsyat seperti di minggu pertama. Secara umum, Laksono (2007: 34) menyimpulkan bahwa isu keadilan sosial selalu mencuat dengan jelas dalam paparan media.

Novenanto (2012: 173-203) menganalisis spanduk-spanduk dan media-media alternatif tentang lumpur Lapindo. Dia menyimpulkan bahwa keberadaan media alternatif yang lahir sebagai respon atas pemberitaan media mainstream turut mempertajam konflik sosial yang ada, yaitu terpecah-pecahnya masyarakat dalam kelompok-kelompok sosial (Novenanto, 2012: 198). Di tingkatan warga, media alternatif sering menjadi media resistensi warga atas skema kompensasi yang diatur pemerintah, ataupun media perjuangan untuk kepentingan warga yang terdampak. Di sisi sebaliknya, dengan alasan marginalisasi yang dilakukan media mainstream, pihak Lapindo menerbitkan media alternatif yang bertujuan membangun opini publik bahwa 
Lapindo hanyalah korban dari bencana ini, bukan penyebab.

Cholil dan Rubi (2012: 205-236) menganalisis sebuah polemik di Forum Apakabar (www.forum.apakabar.ws) yang berjudul, "Urgent Gempa Yogya Mohon Waspada". Mereka membandingkan bagaimana polemik antara wacana keagamaan versus wacana kemanusiaan dalam media online tersebut dan menyimpulkan bahwa diskursus kemanusiaan lebih dominan. Bagi mereka, hal ini wajar karena polemik tersebut berada di media dengan motto "kritis, sekuler dan plural".
Sebagai kesimpulan, review atas berbagai penelitian terdahulu tersebut membuktikan bahwa belum ada penelitian yang membahas representasi bencana dalam foto-foto di media dengan pendekatan analisis wacana kritis. Selain itu, peneliti juga menyimpulkan bahwa kajian tentang representasi bencana di media dan kajian tentang peran media dalam bencana adalah sebuah wilayah baru yang belum banyak dikerjakan oleh peneliti-peneliti media di Indonesia. Bahkan, secara umum, penelitian tentang bencana adalah bidang baru di Indonesia, yang baru mulai berkembang sejak pertengahan 2000an (CRCS 2009). Di titik inilah, penelitian ini mempunyai nilai signifikan bagi pengembangan studi kebencanaan di Indonesia. 


\section{Daftar Pustaka}

Ahimsa-Putra, H.S. 20oo. Peringatan, cobaan, dan takdir: Politik tafsir bencana Merapi. Masyarakat Indonesia, XXVI (1): 27-54.

Arif, Ahmad. 2010. Jurnalisme Bencana, Bencana Jurnalisme: Kesaksian dari Tanah Bencana. Jakarta: Kepustakaan Populer Gramedia.

Bankoff, G. 2004. In the eye of the storm: the social construction of the forces of nature and the climatic and seismic construction of God in the Philippines. Journal of Southeast Asian Studies, 35 (1): 91-111.

Cholil, Suhadi \& Astuti, Emy Rubi. 2012. Agama atau manusia? Analisis diskursus bencana alam dalam media cyber. Dalam Agus Indiyanto and Arqom Kuswanjono (eds), Konstruksi Masyarakat Tangguh Bencana: Kajian Integratif Ilmu, Agama, dan Budaya. Mizan dan CRCS UGM, 205-236.

Donovan, Katherine 2010. Doing social volcanology: exploring volcanic culture in Indonesia. Area, 42 (1): 117-126.

Dove, Michael R. 2007. Volcanic eruptions as metaphor of social integration: a political ecological study of Mount Merapi, Central Java. Dalam Connell, J.; Waddell, E. (Eds.), Environment, Development and Change in Rural Asia-Pacific: Between Local and Global. London: Routledge, 16-37.

Dove, Michael R. 2008. Perception of volcanic eruption as agent of change: on Mt. Merapi volcano, Central Java. Journal of Volcanology and Geothermal Research, 172: 329-337.
Fauzanafi, M. Zamzam. 2012. Menebar Trauma, Menanam Pesona, Menuai Bantuan: Analisa Isi dan Tafsir Awal Foto di Koran dan Tayangan Berita Mengenai Bencana Erupsi Merapi 2010. Lokakarya "Peran Media dalam Penanggulangan Bencana Erupsi Merapi." Yogyakarta, UGM, I1 April 2012.

Gama, Betty. 2009. Jurnalisme Bencana dan Rangsangan Emosional: Studi Hubungan Jurnalisme Bencana Banjir Surat Kabar Solopos dengan Rangsangan Emosional Mahasiswa Univet Bantara Sukoharjo. Scriptura, Vol. 3, Nomor 1, Januari 2009: 818.

Hamilton, Peter. 1997. Representing the Social: France and Frenchness in Post-War Humanist. dalam Representation: Cultural Representations and Signifying Practices. Stuart Hall (ed.). London: Sage Publications.

Hermanto, Budhi. 2011. Jalin Merapi: Sistem Informasi untuk Penanganan Bencana Merapi. Dalam Muzayin Nazaruddin \& Zaki Habibi (eds), Jurnalisme Warga, Radio Publik, dan Pemberitaan Bencana. Yogyakarta: Penerbit Komunikasi UII.

Hermawan, Anang. 2007. Agenda Baru Jurnalisme (Bencana). Bernas Jogja, 22 Februari 2007.

Hight, Joe dan Cait McMahon. 2006. Meliput Trauma: Panduan Dart Centre untuk Para Wartawan, Redaktur dan Manajer. www.dartcentre.org.

Hidayat, Dedy N. 1998. Paradigma dan Perkembangan Penelitian Komunikasi. Jurnal Ikatan Sarjana Komunikasi Indonesia, No. 2/Oktober 1998. 
Hudayana, Bambang et al. 2012. Komunitas Lereng Merapi serta Respon terhadap Erupsi Merapi 2010. Yogyakarta: - the Department of Anthropology, Gadjah Mada University.

Hudayana, Bambang. 2012. Wacana erupsi Merapi dalam KR pada era Orde Baru: Reproduksi kuasa alam dan negara pada jagad pandang orang Jawa. Paper dipresentasikan dalam workshop peran media dalam mitigasi bencana erupsi Gunung Merapi, diselenggarakan UGM, 11 April 2012.

Laksono, P.M. 2007. Visualitas gempa Yogya 27 Mei 2006 (Working paper). The Centre of Asia and Pacific Studies Gadjah Mada University.

Lukmantoro, Triyono. 2007. Bencana dalam berita: Komodifikasi dan simplifikasi fakta. Renai: Kajian Politik Lokal dan SosialHumaniora, 1 (vii): $44-60$.

Masduki. 2007. "=Wajah Ganda Media Massa dalam Advokasi Bencana Alam. Jurnal UNISIA, No. $63 / \mathrm{XXX} / \mathrm{V} / 2007$, Januari Maret 2007.

Macdonell, Diane. 1986. Theoris of Discourse. Oxford: Blackwell.

Nazaruddin, Muzayin. 2007. Jurnalisme bencana: Sebuah tinjauan etis. Jurnal Komunikasi, 1 (2): 163177.

Nazaruddin, Muzayin; Habibi, Zaki (eds.) 2012. Jurnalisme Warga, Radio Publik dan Peliputan Bencana. Yogyakarta: Penerbit Komunikasi UII.

Neumann, Lawrence W. 2003. Social Research Methods: Qualitative and Quantitative Approach. Massachussets: Allyn and Bacon.
Novenanto, Anton. 2012. Imagined disaster: Politik dan (de) konstruksi wacana kasus Lapindo. Dalam Agus Indiyanto and Arqom Kuswanjono (eds), Konstruksi Masyarakat Tangguh Bencana: Kajian Integratif Ilmu, Agama, dan Budaya. Mizan dan CRCS UGM, 173-203.

Olsen, Gorm Rye; Nils Carstensen; Kristian Hoyen. 2003. Humanitarian Aids: What Determines the Level of Emergency Assistance? Media Coverage, Donor Interest and the Aid Business. Disasters: The Journal of Disaster Studies, Policy and Management, Vol. 27 Number 2, June 2003.

Philo, Greg. 2002. Television News and Audiences Understanding of War, Conflict and Disaster. Journalism Studies, Volume 3, Number 2, 2002.

Salim, Agus. 2001. Teori dan Paradigma Penelitian Sosial. Yogyakarta: Tiara Wacana.

"Sejuta Bencana Terencana di Indonesia." www.walhi.or.id/kampanye/ben cana.

Sudibyakto, et al. 2012. Menuju masyarakat tangguh bencana: Tinjauan dari fenomena multibencana di Indonesia. Dalam Agus Indiyanto and Arqom Kuswanjono (eds), Konstruksi Masyarakat Tangguh Bencana: Kajian Integratif Ilmu, Agama, dan Budaya. Bandung: Mizan and CRCS UGM, 7-32.

Rose, Gillian. 2007. Visual Methodologies: An Introduction to The Interpretation of Visual Materials. London: SAGE Publications.

Purwoko, Herudjati. 2007. Melihat banjir di atas koran dari segi semantik. Renai: Kajian Politik Lokal dan Sosial-Humaniora, 1 (vii): 130148. 
Triyoga, Lucas Sasongko. 2010. Merapi dan Orang Jawa: Persepsi dan Kepercayaannya. Jakarta: Grasindo.

Wahyuni, Hermin Indah 2008. Kecenderungan "framing" media massa Indonesia dalam meliput bencana sebagai media event. JSP: Jurnal Ilmu Sosial dan Ilmu Politik, 3 (11): 307-330.
Yusuf, Iwan Awaluddin. 2006. "Ada kuis di tengah gempa": Membangun epistemologi liputan bencana di media. Jurnal Komunikasi, 1(1): 4152 